\title{
Mutant p53 Expression Of Oral Transformed Epithelium Cell In Rats Injected By Benzo[A]Pyrene
}

\author{
Sawitri Dwi Indah Pertami ${ }^{1}$, I Ketut Sudiana ${ }^{2}$, Theresia Indah Budhy ${ }^{2}$, Retno Palupi ${ }^{2}$, Ira Arundina ${ }^{2}$ \\ ${ }^{1}$ Institut Ilmu Kesehatan Bhakti Wiyata, Indonesia. \\ ${ }^{2}$ UniversitasAirlangga, Indonesia \\ sawitripertami90@gmail.com
}

\begin{abstract}
Benzopyrene is a polycyclic aromatic hydrocarbon (PAH) compound that can cause transformation of normal cells into malignant. Benzopyrene enters the body and is converted to benzopyrene-7,8-dihydrodiol-9,10-epoxide (BPDE), making it easier to bind covalently with DNA, causing DNA mutation. Tumor suppressor gene p53, plays an important role in cell cycle arrest at checkpoint phase and inducing apoptosis of cells that have DNA damage. DNA mutation in tumor suppressor genes make cells immortal which results in cell transformation and develops into malignancies. This research is a True Experimental Laboratories with Posttest only control group design. 25 RattusNovergicus were randomly divided into five groups including the control group (without benzopyrene injection) and 4 treatment groups injected with benzopyrene each for 4 weeks (P1), 6 weeks (P2), 8 weeks (P3) and 10 weeks (P4). The transformation cells formed was obtained by HE staining. Mutant p53 expression was obtained by Immunohistochemistry process. Histopathological examination was performed using a 400x magnification light microscope with 5 different visual fields. Therefore, the expression of mutant p53 was calculated and analyzed statistically with the One Way Anova Test. Results of this study showed that there was signifficance difference in mutant p53 expression of oral transformed epithelium cell injected by benzopyrene $(\mathrm{p}=0.000)$ and highest expression was at $10^{\text {th }}$ week. So, it can be concluded that the mutant P53 expression of oral transformed epithelium cells in rats was increased after injected by benzopyrene
\end{abstract}

Keywords : Mutant p53, Oral Transformed Epithelium Cell, Benzopyrene

Received December, 25, 2019; Revised January 24, 2020; Accepted February 15, 2020

(7) (O) STRADA Jurnal Ilmiah Kesehatan, its website, and the articles published there in are licensed under a Creative Commons Attribution-ShareAlike 4.0 International License. 


\section{STRADA Jurnal Ilmiah Kesehatan}

DOI: $10.30994 /$ sjik.v9i1.234

ISSN: 2252-3847 (print); 2614-350X (online)

Vol.9 No.1. May 2020. Page.85-92

\section{INTRODUCTION}

Cell transformation is cell that is genetically unstable due to decreased activity of a Tumor Supressor Gen (TSG) and deactivation of DNA repair pathways when cell develops toward malignancies (Vascotto et al., 2016). Tumor suppressor gene plays a role in controlling cell growth factors. Which includes tumor suppressor gene is retinoblastoma protein (p-Rb) and protein 53 (p53) (Sudiana, 2011). The main role of p53 in the cell cycle is surveillance, activating checkpoint control in the G1/S phase and G2/M phase, or causing apoptosis (Kumar et al., 2015).

Mutation in TSG p53 is the most common mutation associated with cancer development (Das, 2019). Many studies showed that up to $80 \%$ of human oral squamous cell carcinomas harbor mutated p53 tumor suppressor genes. Such a high frequency of mutation suggests an important role for this gene in carcinogenesis as a guardian of genom, which may be represented by the so-called "premalignant" lesions and conditions. At the cellular level, cancer development requires a series of processes involving gene mutation and selection of cell that has the ability to proliferate rapidly, survive, invade, and metastasis. The development of cancer begins when a cell that has a mutation starts to multiply abnormally. Additional mutation is followed by selection of cell in the population that has the ability to grow faster which result in the development of tumor towards into malignancies (Cooper and Robert, 2013).

The development of malignancies is caused by many factors that originate from genetic and environmental factors (radiation, chronic irritation, viruses and carcinogens) (Cooper, 2000). Carcinogen is chemical, biologic, and radiation that can cause cancer both in experimental animal and in human. One chemical carcinogen can stimulate cancer formation by causing DNA damage and inducing gene mutations ibenzo [a] pyrene (Kumar et al., 2018).

Benzo(a)pyrene is commonly found in tobacco smoke. Furthermore, smoking is an undisputed cause of $80-90 \%$ of lung cancer, and is involved in cancer of the oral cavity, pharynx, larynx and esophagus. Besides being found in tobacco smoke, exhaust gas and diesel engine, food that is burned with charcoal, and smoked meat or fish. Benzopyrene which enters the body and is activated metabolically is known to cause cytotoxic, teratogenic, genotoxic, mutagenic, and carcinogenic effects (Shi et al., 2011). Benzopyrene $(\mathrm{C} 20 \mathrm{H} 12)$ is a combination of pyrene and phenylene. The two benzopyrene isomer species are benzo [a] pyrene and what is rarely found is benzo [e] pyrene. The two isomer species are included in polycyclic aromatic hydrocarbon compounds (Hummel et al, 2018).

Polycyclic hydrocarbon compound is the most powerful carcinogens ever known. This substance requires metabolic activation and can induce tumors in various tissues and species. Benzopyrene is a highly reactive electrophile (has an electron deficient atom) and can react with nucleophilic (electron rich) sites in cell, especially DNA (Kumar et al., 2018). B(a)p has been widely used in in vivo carcinogenesis research in mice, rats and hamsters as positive control. B[a]P causes DNA damage which stimulates the formation of DNA mutation, cell transformation, carcinogenesis and or cell death. If applied to the skin, this substance can cause skin cancer, if injected sub cutisally this substance will induce sarcoma. If inserted into a particular organ, local cancer will occur (Kumar et al., 2015). Therefore, the aim of this study was to determine the mutant P53 expression of oral transformed epithelium cells in rats after injected by benzopyrene 


\section{STRADA Jurnal Ilmiah Kesehatan}

DOI: $10.30994 /$ sjik.v9i1.234

\section{METHODS}

This study has received ethical approval from the Ethics Committee of the Faculty of Dentistry, UniversitasAirlangga, Surabaya. This research is a true experimental laboratory with posttest only group design. The sample of this study was 5 Rattus norvegicus wistar strains for each group calculated based on the Lemeshow formula. The criteria for the sample of this study was the RattusNorvegicuswistar strain aged 2-3 months and weighing around 160-200g which was kept in the same place and given the same food.

Rattus norvegicus in this study was obtained from the Biochemical Laboratory of the Faculty of Medicine, UniversitasAirlangga, which was acclimated for 7 days by being put into a cage with a size of $60 \mathrm{~cm} \times 65 \mathrm{~cm} \times 80 \mathrm{~cm}$ for 5 rats and placed in a room with enough air and light so that not humid, far from noise and not exposed to direct sunlight. Rats were given food and drink every day on an ad libitum basis, after that, a weight was weighed to meet the sample criteria and then divided randomly into five groups namely the control group (without benzopyrene induction) and 4 treatment groups namely P1 (benzopyrene injection for 4 weeks ), P2 (benzopyrene injection for 6 weeks), P3 (benzopyrene injection for 8 weeks), P4 (benzopyrene injection for 10 weeks).

Benzopyrene (Merck, Sigma Aldrich Pte. Ltd., St. Louis, USA) used in the form of solid powder at a dose of $8 \mathrm{mg} / \mathrm{kg}$ dissolved in olivarumolium (Borges Olive Oil) in a ratio of $1: 2$. Giving benzopyrene is done by injection using a syringe with a depth of $2-3 \mathrm{~mm}$ in the oral buccal mucosa of $0.07 \mathrm{ml} 2$ times a week for 4, 6.8, and 10 weeks.

At the end of the week, Rattus was sacrificed with ether inhaled. The next step, take tissue in the area around the buccal mucosa which is clinically in the form of a tumor that indicates carcinogenesis has occurred in the area using surgical scissors and blade. Tumors are characterized as abnormal nodules on the buccal mucosa with a hard and immovable consistency. The tissue is cut with a thickness of $2-3 \mathrm{~mm}$, a length of $1 \mathrm{~cm}$, width $0.5 \mathrm{~cm}$ and a further fixation is performed in NBF 10\% (Budhy, 2000) to be processed into paraffin block. The paraffin block is then cut with a thickness of $4 \mu$. and placed on a microscope slide for HE staining and immunohistochemical processes (Bancroft, 2008).

Histopathological examination of the formed transform cell was determined by using the "Hematoxyllin eosin" (HE) staining technique. The presence of cell that has p53 gene suppressor tumor mutation is examined by Immunohistochemistry staining using monoclonal antibodies (Santa Cruz Biotechnology). Histopathological examination in this research used an optical microscope (Leica DM750 with Leica ICC50HD optical camera, by Leica Microsystem Europe) with 400x magnification at 5 different fields of view. Mutant P53 expression is characterized by a brown color with a strong intensity in the nucleus and cytoplasm.

A Shapiro-Wilk normality test was carried out to determine the distribution data of this study, followed by a Levene's variance homogeneity test. If the results showed normally distributed data, a parametric One Way Anova test was subsequently performed. The analysis was carried out using SPSS for Windows version 17. 


\section{STRADA Jurnal Ilmiah Kesehatan}

DOI: $10.30994 /$ sjik.v9i1.234

\section{RESULTS}

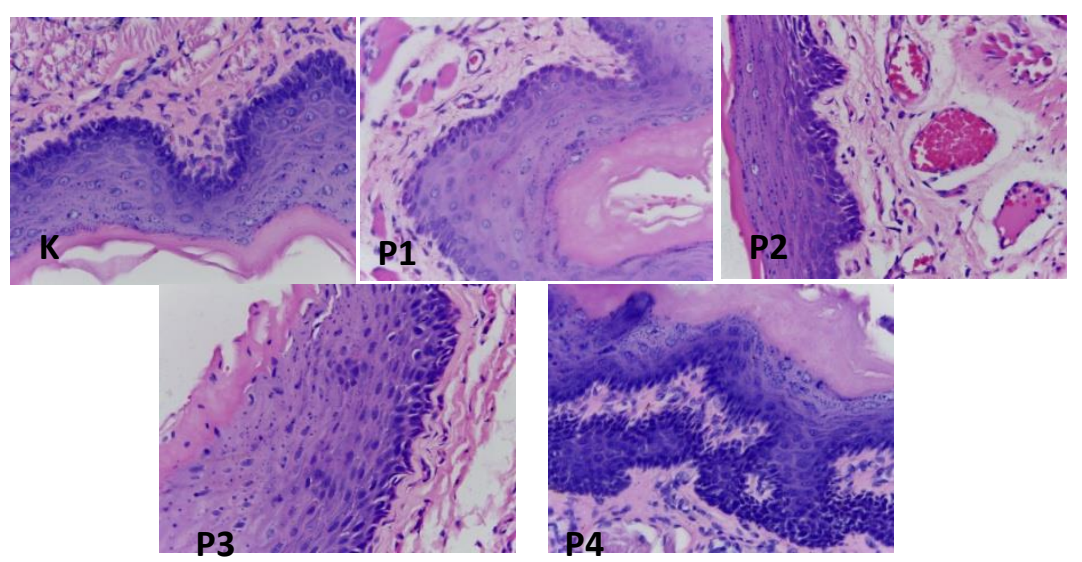

Figure 1. Histopathological picture of transformed cell formation in squamous epithelial cell of the oral cavity in groups K,P1, P2, P3, P4

Figure 1 shows a histopathological picture of transformation cell resulting from the Hematoxylin eosin staining. In group $\mathrm{K}$, there were no transformed cell, squamous epithelium of the normal oral cavity was characterized by uniform cell shape and size, no change in the nucleus and cytoplasm ratio. In the P1 group, the number of macrophage and vascular proliferation were increased, hyperkeratinization, but the cell shape and size was normal, no hyperchromatic cell nucleus were found, the retepeg form is still normal. In the P2 group, that has been injected by benzopyrene for 6 weeks, there were transformed cell in squamous epithelium, blood vessel proliferation and the number of macrophage was increased, the retepeg form is still normal. In the P3 group, which was injected with benzopyrene for 8 weeks, there was enhancement cell transformation, hyperkeratization and retepeg changes began to form. Cell begins to vary in shape and size and some hyperchromatic cell were found.

The most transformation cell was found in the P4 group, after being injected with benzopyrene for 10 weeks. In the P4 group squamous epithelial cell vary in shape and size, hyperkeratinization, hyperchromatic nucleus, with non fused retepeg form. There was an increase in basaloid cell proliferation, the formation of basal cell becomes irregular, an increase in the ratio of nucleus and cytoplasm ( $\mathrm{n} / \mathrm{c}$ ratio).

To ensure DNA mutation in oral transformed cell, mutant p53 expression was checked. The results of immunohistochemistry staining as shown in the picture below.

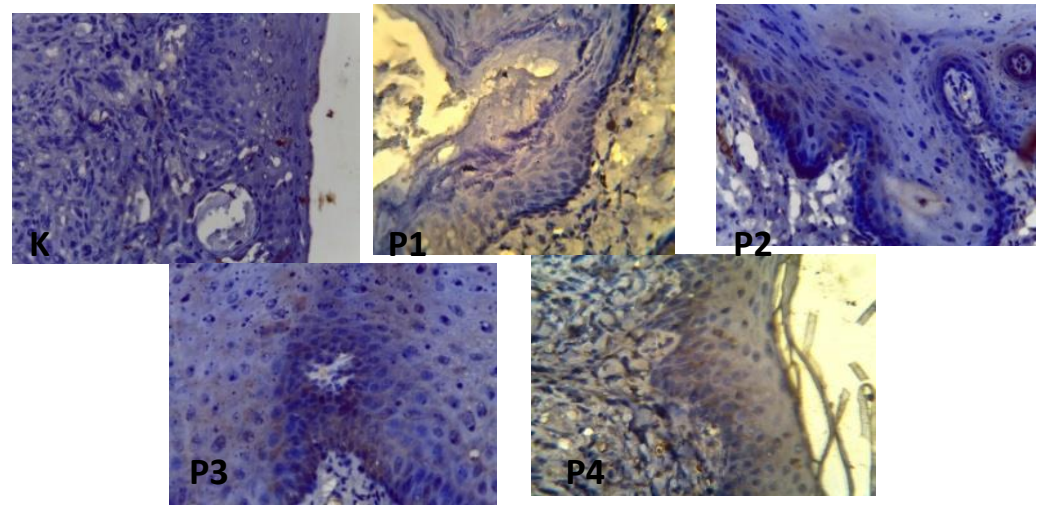

Figure 2. Immunohistochemistry staining of mutant p53 expression 


\section{STRADA Jurnal Ilmiah Kesehatan}

DOI: $10.30994 /$ sjik.v9i1.234

Positive mutant p53 gene expression is characterized by a brown nucleus and cytoplasm. Figure 2 showed that the mutant p53 expression was not found in the control group. Mutant p53 gene expression was found in the P1, P2, P3, and P4 groups, with the most expression in the $\mathrm{P} 4$ group, namely the group injected with benzopyrene for 10 weeks. From the results of SaphiroWilk test showed the data of this study were normally distributed $(p>0.05)$. Homogeneity variance test result shows that the levene data were homogeneous ( $p>0.05)$. Therefore, the data were analyzed by using the One Way Anova parametric test with result like the table below.

Table 1. The test result for One Way Anova Mutant p53 expression in epithelial cell transforming the oral cavity

\begin{tabular}{cccc}
\hline Group & $\mathrm{n}$ & $\begin{array}{c}\text { HSP 70 } \\
\text { Mean } \pm \text { SD }\end{array}$ & $\begin{array}{c}\text { One Way } \\
\text { ANOVA }\end{array}$ \\
\hline K & 5 & $0.0 \pm 0,00^{\mathrm{a}}$ & \\
P1 & 5 & $2.0 \pm 0.71^{\mathrm{b}}$ & \\
P2 & 5 & $2.2 \pm 0.84^{\mathrm{b}}$ & $\mathrm{p}=0.000$ \\
P3 & 5 & $3.8 \pm 1.64^{\mathrm{c}}$ & \\
P4 & 5 & $4.8 \pm 0.84^{\mathrm{d}}$ & \\
\hline
\end{tabular}

Note: the same supercriptabcd shows no significant differences between groups by using the Least Significant Difference (LSD) test

Based on the result of One Way Anova test expression of mutant p53 gene in epithelial cell transforming the oral cavity, there were significant differences between study groups $(p=0.000)$, with the most significant difference being in the P4 group.

\section{DISCUSSION}

Based on the result of Hematoxyllin eosin staining in Figure 1, the most transformation cell was formed at week 10, as the squamous epithelium of the oral cavity was injected with benzopyrene. This is thought to be due to the ability of benzopyrene to cause genotoxic and carcinogenic effects in the area injected with benzopyrene. (Shi et al.) Exposure to benzopyrene can cause DNA damage, it is the most important process in the process of cancer, where this process occurs in a long time along with the accumulation of carcinogenic substances as the main cause of cancer (Hummel et al., 2018).

To confirm the mutation of gene in the oral epithelial cell, in this research, an immunohistochemical examination of mutant p53 gene expression was performed. Protein 53, which is encoded by p-53, is a tumor suppressor gene (TSG) that plays an important role in DNA repair, cell cycle termination, and apoptosis. Activation of normal p53 (wild type p53) by agents that damage DNA causes the cell cycle to stop in G1 and DNA repair begins, due to increase transcription of c21 cyclin dependent kinase inhibitors (CDK-21). p53 also helps the repair process directly by inducing the GADD45 (Growth arrest and DNA damage) gene, which encodes a protein for DNA repair. If DNA repair is successful, the cell can continue its cycle. However, if it fails, apoptosis will occur due to the activation of the BAX gene by p53.

Based on the figure 2, the lowest mutant p53 gene expression was found in the benzopyrene injected group for 4 weeks. The low expression of mutant p53 genes in this group is suspected because at the beginning of the week after injection, there was the ability of DNA repair gene in repairing cell damage that occurs. Physiologically, there is a system in the cell that regulates the composition of nucleotides in DNA chains that 


\section{STRADA Jurnal Ilmiah Kesehatan}

DOI: $10.30994 /$ sjik.v9i1.234

undergo mutations, called DNA repair. When DNA damage occurs due to exposure to carcinogens, a cell response will appear called NER (Nucleotide Excision Repair) to repair damaged DNA structures through the stages of damage recognition, incision, excision, syntesis repair and ligation. (Sudiana, 2011). According to Irmawati et al. (2018), at the beginning of the week after the injection of benzopyrene, gene mutation that occurs stimulate the activity of the GADD45 gene which plays a role in the NER pathway by interacting with Proliferating Cell Nuclear Antigen (PCNA) to help the DNA repair process. GADD45 expression is known to increase along with the longer cell exposed to benzopyrene

Table 1 shows that the $\mathrm{P} 4$ group injected with benzopyrene for 10 weeks explained the most significant increase in mutant p53 gene expression. This may be due to the longer administration of benzopyrene injection causing an imbalance between DNA damage and the DNA repair process. Benzopyrene entering the body is first oxidized by the cytochrome P4501A1 (CYP1A1) enzyme, producing several products, one of which is benzo(a)pyrene-7,8 epoxide which is then metabolized by benzopyrene-7,8 dihydrodiol, and converted to benzopyrene-7,8 dihydrodiol-9,10 epoxide (BPDE) with the help of the CYP1A1 enzyme. It is BPDE that will bind covalently to DNA, which in turn can cause DNA mutation (Jiang et al., 2007). Increasing the amount of carcinogen which absorbed by mucosal epithelial cells will increase the risk of tumor supressor gen mutation. The gene mutations can indicate whether changes in malignant epithelial cells of the oral mucosa have been initiated. Similarly, in this study, the increased expression of mutant p53 due to benzopyrene injection shows that gene mutations can normally affect the cell cycle and initiate the risk of malignancy (Angriany et al.,2019).

In cell that has mutation in the tumor suppressor gene p53, DNA damage that occurs does not trigger the cell cycle arrest or DNA repair. Thus, genetically damaged cell will continue to proliferate and stimulate normal cell transformation into malignancies development. This is because the mutant p53 formed is inactive, so it does not trigger the formation of $\mathrm{p} 21$. The low level of $\mathrm{p} 21$ causes Cyclin dependent kinase not to be inhibited, so the cycle of cell division that is damaged by DNA continues. On the other hand, the p53 mutation does not trigger the activity of the pro apoptotic BAX gene which ultimately causes the cell to not be able to be adopted (Sudiana, 2011). If homozygous loss of p53 occurs, DNA damage will continue without repair, mutation becomes permanent in cell that divides and cell moves towards one way paths to achieve malignant transformation (Kumar et al., 2018).

\section{CONCLUSION}

Therefore, it can be concluded that there was an increase in the expression of mutant p53 gene in oral transformed epithelium cell after being injected by benzopyrene where the expression was most abundant in the $\mathrm{P} 4$ group, which has been injected with benzopyrene for 10 weeks.

\section{REFERENCES}

Angriany, Dian, Diah SE., Adiastuti EP., Hening TH., Rosnah BZ. (2019). Effects of sidestream tobacco smoke on P53 expressions in Rattus novergicus tongue epithelial mucosa. Dental Journal(Majalah Kedokteran Gigi). 52(3), 138-141

Bancroft, JD. (2008). Theory and Practice of Histological Techniques. Elsevier Health Sciences 


\section{STRADA Jurnal Ilmiah Kesehatan}

DOI: $\underline{10.30994 / \text { sjik.v9i1.234 }}$

ISSN: 2252-3847 (print); 2614-350X (online)

Vol.9 No.1. May 2020. Page.85-92

Budhy, TI. (2000). Mekanisme Nekrosis Sel Kanker Oleh Sel Imunokompeten Makrofag Karena Pemberian Ektrak Teh Hitam pada Mukosa Rongga Mulut yang Terpapar Benzopirine. Disertasi. Airlangga University Library.

Budhy, TI., (2018). Molecular Grading of Oral Squamous Cell Carcinomas Infected with EBV. Asian Pacific Journal of Cancer Prevention, Vol 19( 7), 1793-1796. doi:10.22034/APJCP.2018.19.7.1793

Cawson RA, Odell EW. (2000). Oral Cancer. $6^{\text {th }}$ ed. London: Churchill Livingstone.pp.228-238.

Cooper , GM., Robert, EH. (2013). The Cell: A Molecular Approach 6th edition.USA: Sinauer Associates, Inc

Das, AB. (2019). Disease association of human tumor suppressor genes. Molecular Genetics and Genomics. https://doi.org/10.1007/s00438-019-01557-9

Epstein J.B, Der Waal I, 2008. Oral Cancer, in : Greenberg M.S, Glick M, Ship J.A., Burket"s Oral Medicine, 11th ed. BC Decker Inc, Hamilton, 153-4

Guo, Y., Kusheng, W.,Xia H., Xijin, X.(2011). Sources, Distribution, and Toxicity of Polycyclic Aromatic Hydrocarbons. Journal of Environmental Health, 73(9), 22-25.

Hummel, JM, Erin PM, Sidden LK, Sandra LU, Tammie M, Kim AA, Kenneth WT, Ted JO, Graham B, Sharon KK, Stuart H, Jordan S., Susan CT, William MB, David EW.( 2018). Pharmacokinetics of $\left[{ }^{14} \mathrm{C}\right]$-Benzo[a]pyrene $(\mathrm{BaP})$ in humans: Impact of CoAdministration of smoked salmon and $\mathrm{BaP}$ dietary restriction. Food Chemical Toxicology. 2018 May;115:136-147. doi: 10.1016/j.fct.2018.03.003

Irmawati, A., Harjanto JM, IK Sudiana. (2019). 'The GADD45 and Wild p53 Expressions Resulting from Moderate Swimming Exercise on Mus musculus Injected by Benzopyrene. Journal of International Dental and Medical Research ISSN 1309100X 12(3). pp.964-968.

Irmawati, Anis. (2018). Mekanisme Hambatan Pembentukan Sel Transform Pada Sel Epitel Skuamosa Rongga Mulut Akibat Latihan Renang Intensitas Sedang (Pada Mus musculus strain Swiss Webster Yang Dipapar Benzopyrene). Disertasi thesis, Universitas Airlangga.

Kumar V, Abbas AK, John C.Aster. (2018). Robbins Basic Pathology of Disease. 10th ed. Philadelphia, Elsevier.

Kumar V, Abbas AK, John C.Aster.(2015). Robbins and Cotran Pathologic Basis of Disease. 9th ed. Philadelphia, Elsevier.

Latest global cancer data:Cancer burden rises to 18.1 million new cases and 9.6 million cancer deaths in 2018. International Agency for Research on Cancer (IARC).2018. WHO

Manjunath, S., C. Girish, H., Darshan, DD., Shaista, H., Husain, A., Mohammad, F., Mohammed, YMA. (2019). An immunohistochemical study of p53 expressions in oral submucous fibrosis. Journal of Oral and Maxillofacial Pathology, 23(2), 308. doi: 10.4103/jomfp.JOMFP_277_17

Newkirk, K. M., Brannick, E. M., \& Kusewitt, D. F. (2017). Neoplasia and Tumor Biology. Pathologic Basis of Veterinary Disease, 286-321.e1. doi:10.1016/b978-0323-35775-3.00006

Shafy, HIA., Mona, SMM. (2016). A review on polycyclic aromatic hydrocarbons: Source, environmental impact, effect on human health and remediation.Egyptian Journal of Petroleum, 25(1), 107-123. https://doi.org/10.1016/j.ejpe.2015.03.011 


\section{STRADA Jurnal Ilmiah Kesehatan}

DOI: $10.30994 /$ sjik.v9i1.234

Siregar, C., Eddy, BW., Sudiana, IK. Effect of Butyric Acid on p53 Expression and Apoptosis in Colon Epithelial Cells in Mice after Treated with 9,10-dimethyl-1,2 benz(a)anthracene.(2018) Procedia Chemistry,18, 141 - 146. Published by Elsevier B.V. doi: 10.1016/j.proche.2016.01.022

Sudiana I.K, 2011. Patobiologi Molekuler Kanker. Jakarta: Salemba medika. Hal: 53-59

Sudiana I.K,2014.Imunopatobiologi Molekuler.Surabaya:Airlangga University Press.Hal:23-33

Vascotto, C., Poletto, M., and Tell, G. (2016). Understanding the basics for translating the base excision repair pathway from benchtop to bedside in cancer treatment. DNA Repair in Cancer Therapy, 83-114. doi:10.1016/b978-0-12-803582-5.00003-6 